\title{
CLIMATE CHANGE AND THE INUIT: BRINGING AN EFFECTIVE HUMAN RIGHTS CLAIM TO THE UNITED NATIONS
}

\author{
Andrew D. Emhardt ${ }^{*}$ \\ INTRODUCTION
}

I think over again,

My small adventures,

My fears,

Those small ones that seemed so big,

For all the vital things

I had to get and to reach

And yet there is only one great thing:

To live to see the great day that dawns

And the light that fills the world.

- Old Inuit Song ${ }^{1}$

There is a strong connection between climate change and human rights infringements in the Arctic. ${ }^{2}$ Global warming poses severe threats to the livelihood of the native Arctic people. ${ }^{3}$ The levels of sea ice in the arctic were the lowest they have ever been in $2012 .{ }^{4}$ Because most Inuit live along coastlines and river valleys, their health and culture depends on the harvest of fish, whales, and other wildlife. As sea ice levels continue to drop, the populations of these sources of food are dropping as well. ${ }^{5}$ With the

* Andrew Emhardt is a 2014 graduate from Robert H. McKinney School of Law and IUPUI School of Public and Environmental Affairs with a dual J.D./Master of Public Affairs degree. He graduated from DePauw University with a Bachelor of Arts in Political Science in 2010. Andrew would like to thank his professors and peers for their invaluable assistance, and his fiancée for her love and support.

1. See Inuit Literature, Indigenous Peoples Literature, http://www.indigenouspeople.net/inuit.htm (last updated Dec. 18, 2013, archived at http://perma.cc/V7DB-T4WG).

2. See Jennifer Cassel, Enforcing Environmental Human Rights: Selected Strategies of U.S. NGOs, 6 Nw. U. J. INT'L HuM. RTS. 104 (2007).

3. Donald M. Goldberg, Global Warming and Human Rights: A Case Study FROM THE ARCTIC 4-6 (2002).

4. Maria-José Viñas, Arctic Sea Ice Minimum in 2013 Is 6th-Lowest on Record, NAT'L Aeronautics \& Space Admin. (Sept. 23, 2013), http://climate.nasa.gov/news/986, archived at http://perma.cc/5TA7-VS7S.

5. GoldBerg, supra note 3, at 5; see also Ed Struzick, As Arctic Melts, Inuit Face Tensions with the Outside World, ENVIRONMENT 360 (2012), archived at http://perma.cc/WH8Y-KWNL. This news article states "the rapid retreat of the sea ice that has defined the Arctic ecosystem for thousands of years is threatening the existence and movements of creatures that have long been at the heart of Inuit subsistence culture - 
thawing of permafrost, the frozen surface layer of soil, the Inuit must rethink their old ways of construction or lose their homes. ${ }^{6}$ This thawing is causing damage to houses, roads, airports, and pipelines. ${ }^{7}$

There is no easy solution to the problems presented by climate change in the Arctic, but it is now clear that a court-based approach cannot make an impact. Real solutions must be the result of a concerted effort by the developed world, but the world will not take action unless there is clear support. There, non-governmental organizations (NGOs) must take up the call and collaborate with the Inuit populations that face significant threats to their cultural freedom.

This Note is divided into seven parts. Part I addresses two legal approaches to the intersection of climate change and Inuit rights. Part II addresses the history of the Inuit peoples and their special relationship to the wildlife and surrounding lands. Part III discusses the impact of climate change in the Arctic region and how it threatens this way of life. Part IV addresses the primary strategies for change and policymaking, with a discussion on the successes and failures. Part $\mathrm{V}$ focuses on the unique role of NGOs and non-profits in affecting Inuit's issues. Finally, Part VI discusses the need for NGOs to increase collaboration and include Inuit in their organizational structure. Part VII concludes that, despite the significant pressures for economic development, NGOs must ensure that Inuit, not industry, decide the path of these indigenous people.

\section{LEGAL APPROACHES}

There are two major approaches to correcting the impact of climate change on Inuit populations. First, localized groups can bring claims against those responsible for global warming in federal court. ${ }^{8}$ The claim can be of public nuisance or other property rights issues. ${ }^{9}$ The second alternative is to bring a human rights claim to the United Nations. This is the better alternative for two reasons. First, since Inuit are spread across seven nations, ${ }^{10}$ a ruling in one state is unlikely to have a lasting impact in another. Second, global warming and climate change are not issues that a court alone can remedy. Therefore, the appropriate body to which to bring these claims is the United Nations.

However, bringing a claim to the United Nations is not a simple task. This Note argues that NGOs must carry the burden of bringing an effective

whales, seals, polar bears, and fish."

6. Struzick, supra note 5.

7. GOLDBERG, supra note 3 , at 5.

8. E.g., Native Vill. of Kivalina v. ExxonMobil Corp., 696 F.3d 849 (9th Cir. 2012), cert. denied, 133 S. Ct. 2390 (2013).

9. Id. at 855; Cassel, supra note 2, at 106.

10. United States, Canada, Norway, Sweden, Greenland, Russia, and Finland. INDIGENOUS PARLIAMENT, infra note 46 , at 8 . 
human rights claim, but this can only work with overwhelming public support. Though there are many NGOs in the field, their efforts are disjointed. NGOs must make greater efforts to collaborate with local Inuit leaders to effectively rally public opinion and awareness.

\section{A. The Failures of Public Nuisance}

In Native Village of Kivalina v. ExxonMobil Corp. ${ }^{11}$ the Ninth Circuit of the United States exposed the critical problems of a court-based approach. In Kivalina, concerned villagers brought a claim of public nuisance against ExxonMobil and twenty-two other "Energy Producers" for their contribution to global warming. ${ }^{12}$ The villagers claimed that the Energy Producers'Tgreenhouse gas (GHG) emissions forced them to relocate. ${ }^{13}$ The District Circuit in Kivalina ruled that the villagers brought a nonjusticiable political question and that the tribe and the city lacked standing. ${ }^{14}$ On appeal, the Ninth Circuit emphasized that federal law, through the Clean Air Act, had displaced the claim. ${ }^{15}$

The village of Kivalina is a 400-member tribe of Inuit on the tip of a barrier reef, seventy miles north of the Arctic Circle. ${ }^{16}$ The village is selfgoverning and federally recognized. ${ }^{17}$ The villagers "depend on the sea ice that forms on their coastline in the fall, winter, and spring each year to shield them from powerful coastal storms." 18 In recent years, however, the sea ice has formed later, broken up earlier, and been much thinner than expected, meaning the village has lost its "shield" from coastal storms. ${ }^{19}$ The village blames the inevitable destruction of its lands on global warming, with the GHGs emitted from the defendants as the culprit. ${ }^{20}$ They allege that this "constitute[s] a substantial and unreasonable interference with public rights, including the rights to use and enjoy public and private property in Kivalina." 21

The Energy Producers moved to dismiss the action for lack of subject matter jurisdiction, arguing that Kivalina's claims raise "inherently nonjusticiable political questions because to adjudicate its claims, the court would have to determine the point at which GHG emissions would become

11. Kivalina, 696 F.3d at 849 .

12. Id. at 853 .

13. Id.

14. Id. at 854 .

15. Id. at 857 .

16. Id. at 853 .

17. Id.

18. $I d$.

19. Id.

20. $I d$.

21. Id. at 854 . 
excessive without the guidance from the political branches."22 They further asserted that Kivalina was unable to establish any facts that its injuries were "fairly traceable" to the defendants. ${ }^{23}$

The Ninth Circuit drew on the Supreme Court's decision in American Electric Power Co., Inc. v. Connecticut, where eight states and the city of New York brought a public nuisance claim against the five largest emitters of carbon dioxide in the United States. ${ }^{24}$ The Supreme Court held that the Clean Air Act and Environmental Protection Agency (EPA) regulations displaced the cause of action and any remedy. ${ }^{25}$ The Ninth Circuit reasoned:

The doctrine of displacement is an issue of separation of powers between the judicial and legislative branches, not the judicial and executive branches. When the Supreme Court concluded that Congress had acted to empower the EPA to regulate greenhouse gas emissions, it was a determination that Congress had "spoken directly" to the issue by legislation. Congressional action, not executive action is the touchstone of displacement analysis. ${ }^{26}$

The Ninth Circuit concluded its analysis by stating, "Kivalina's dire circumstance must rest in the hands of the legislative and executive branches of our government, not the federal common law." 27

That final observation underlines the problems of a court-based approach. There are simply too many barriers to effectively bring a claim under public nuisance. Even if Congress were to take any more steps to abate GHG emissions, there would still be a crucial question remaining: What will the rest of the world do? ${ }^{28}$ Particularly in the case of Inuit peoples, the action must come from the United Nations, with all developing nations united in their decision to take measures for real change.

\section{B. The Hope of a Human Rights Claim}

The Universal Declaration of Human Rights provides a glimmer of

22. Id.

23. Id.

24. Kivalina, 131 S. Ct. at 2527,2529 (2011).

25. Id. at 2537.

26. Kivalina, 696 F.3d at 857 (citations omitted).

27. Id. at 858 .

28. While the Inter-American Court of Human Rights (IACHR) could hear these claims, the problem of a ruling resulting in action is the same; the IACHR's jurisdiction is limited and contribution to climate change is a global problem. Rules of Procedure of the InterAmerican Commission on Human Rights, Organization of American States (Sept. 2, 2014), archived at http://perma.cc/ZK5-4NFN. 
hope for the Inuit. ${ }^{29}$ Article 22 of the Declaration explicitly provides the right to cultural freedom, although the document itself has no binding effect. $^{30}$ The 1978 World Conference to Combat Racism and Racial Discrimination "endorses the right of indigenous peoples to maintain their traditional structure of economy and culture, including their own language, and also recognizes the special relationship of indigenous peoples to their land and stresses that their land, land rights and natural resources should not be taken away from them." 31

In specific application to the Inuit, the Canadian Constitution secures " $[t]$ he existing aboriginal and treaty rights of the aboriginal peoples . . . . '[T]reaty rights'nincludes rights that now exist by way of land claims agreements or may be so acquired." 32 Therefore, the right to minimal selfdetermination can be understood to give the Inuit people, at the very least, the fundamental right to exist. This right grants the Inuit protection from "ethnocide" and secures their right to cultural participation. ${ }^{33}$

As indigenous populations depend on the environment to survive, the developed world's intrusions through environmental degradation deny their right to exist. ${ }^{34}$ When advocating for the protection of his native lands, the Coordinator of the Indian Nations Unions stated:

The only possible place for [indigenous] people to live and to re-establish our existence, to speak to our Gods, to speak to our nature, to weave our lives is where our God created us .... We are not idiots to believe that there is possibility of life for us outside of where the origin of our life is. Respect our place of living, do not degrade our living conditions, respect this life .... [T] he only thing we have is the right to cry for our dignity and the need to live in our land. ${ }^{35}$

29. Universal Declaration of Human Rights, G.A. Res. 217A (III), U.N. Doc. A/810 (Dec. 10, 1948).

30. Id. art. 22.

31. The Declarations and Programmes of Action adopted by the First (1978) World Conference to Combat Racism and Racial Discrimination, U.N. Sales No.E.79.XIV.2, ch. II (Aug. 14-25, 1978), archived at http://perma.cc/TT5L-XARD.

32. Rights of the Aboriginal Peoples of Canada, 35, Part II of the Constitution Act, 1982, being Schedule B to the Canada Act, 1982, c. 11 (U.K.) archived at http://perma.cc/WS2P-H6BL.

33. William Andrew Shutkin, Note, International Human Rights Law and the Earth: The Protection of Indigenous Peoples and the Environment, 31 VA. J. INT'L L. 479, 489 (1991).

34. Id. at 490 .

35. Id. (quoting A. Krenak at the World Commission on Environment and Development). 
This, however, is the constant plight of indigenous populations. "[T]he history of indigenous people is . . . the chronicle of their unsuccessful attempts to defend their land against invaders." ${ }^{36}$ Now that the climate is changing, the Inuit's need to defend their land is more necessary, yet more elusive than ever. When members of the international community deny that climate change is actually a problem, naming the specific culprit of this new invasion is next to impossible.

Instead of outlining new plans or forums for the United Nations to implement to a change in policy, the focus should be on fostering a bottomup movement. The United Nations has recognized the importance of this approach, stating that it "allows us to appraise the most pressing needs of a highly inequitable global society, with greatly differing social, environmental and economic levels of development." ${ }^{, 37}$ The High Commissioner further stated: "A human-rights based approach must be taken so that progress is not made at the cost of the most vulnerable and discriminated against members of society., ${ }^{38}$

The High Commissioner Report stated that "a human rights-based approach to climate change is also pragmatically necessary because litigation alone is not working." 39 The report stated that while States are legally obligated to respect human rights, "efforts to invoke environmental legal obligations have not created the tangible results necessary to be a sufficient solution." $" 40$

Another critical element of the High Commissioner Report is that it encourages "stronger cooperation between the human rights community and the climate change-awareness community." "The report emphasizes that "[t]he significant problem is a lack of cooperation, coordination, and coherence" 42 between the two groups. The report points to the lack of communication at the domestic and international level between civil society and government agencies, and states that this will continue to create a "protection gap" until the two communities are "coordinated and successfully operationalized." 43

The High Commissioner Report, though immensely important in defining the scope of a human rights-based approach, does not clearly

36. Hurst Hannum, New Developments in Indigenous Rights, 28 VA. J. INT’L L. 649, 667 (1988).

37. Human Rights Council, Rep. of the United Nations High Commissioner for Human Rights on the Outcome of the Seminar Addressing the Adverse Impacts of Climate Change on the Full Enjoyment of Human Rights, 4, Apr. 10, 2012, UN Doc. A/HRC/20/7 (2012) [hereinafter High Commissioner Report].

38. Id.

39. Id. at 8 .

40. Id.

41. Id. at 10 .

42. Id. at 12 .

43. Id. 
elucidate the issue of human rights versus climate change for two reasons. First, there are already organizations that recognize the link between human rights and climate change. Second, it ignores the deficiencies of a top-down approach to the problem. The best solution is not only for NGOs to collaborate with one another, but also to collaborate with the indigenous people they seek to represent.

This Note explores the relationship of Inuit peoples to NGOs and asserts that NGOs must make greater efforts to collaborate with the indigenous Arctic groups in order to bring an effective human rights claim to the United Nations. ${ }^{44}$ In this arena, NGOs have the financial resources and willpower to create a lasting change, but there is still work to be done. NGOs should open their organizational doors to increase collaboration and make more efforts to include Inuit leaders in their management structure. The ultimate goal is to foster a "grassroots" movement that gives the Inuit a voice loud enough to be heard-and addressed - with the United Nations. But first, it is important to address the history of the Inuit and impact of climate change in the Arctic.

\section{THE INUIT}

\section{A. Pre-European Contact}

Prior to their encounters with Europeans, Inuit were completely selfsufficient. ${ }^{45}$ Inuit inhabit Arctic and Subarctic regions of Alaska, Canada, Greenland, Norway, Russia, Finland, and Sweden. ${ }^{46}$ While the term "Inuit" describes a series of distinct cultures, ${ }^{47}$ they all share a common history; and most importantly, they share a common future. To a "southerner," life in the Arctic is harsh, as winter temperatures can reach negative forty degrees Fahrenheit, ${ }^{48}$ and northern villages face months without a sunrise. ${ }^{49}$

44. This Note is limited in scope to the Inuit in order to explore in appropriate depth the issues presented by such an approach. However, the Inuit are not the only indigenous population that can benefit from this approach.

45. Pauktutit Inuit Women of Canada, The Inuit Way: A Guide to Inuit Culture 4 (2006) [hereinafter THE INUIT WAY].

46. Kathrin Wessendorf, An Indigenous Parliament?: Realities AND Perspectives in Russia AND the Circumpolar North 8 (2005) [hereinafter AN INDIGENOUS PARLIAMENT].

47. Id.

48. Helen Dwyer \& Michael Burgan, Inuit: History and Culture 18 (2012).

49. Mike Heard, Barrow Alaska Has Sunlight after 65 Days of Darkness, KBZK.COM (Jan. 23, 2013, 8:42 AM), http://www.kbzk.com/news/barrow-alaska-has-sunlight-after-65days-of-darkness/, archived at http://perma.cc/N3QU-T9D4. At the North Pole, the sun does not rise between October and March. Daylight, Darkness and Changing of the Seasons

at the North Pole, NAT'L OCEANIC AND ATMOSPHERIC ADMIN., http://www.arctic.noaa.gov/gallery_np_seasons.html (last visited Jan. 15, 2014, archived at http://perma.cc/KAE2-WWP3). 
Before European contact, Inuit lived in small nomadic groups and were dependent on hunting, fishing, and gathering to meet their needs. ${ }^{50}$ To resolve disputes, they followed community customs. ${ }^{51}$ That is, they used nothing more than informal structures to maintain peace between groups. ${ }^{52}$

In the early 1950 s, the Canadian government began to move Inuit into permanent settlements. ${ }^{53}$ While many adopted the features of southern life, many more continued to live according to their traditional values and maintained "close ties to the land and consider their relationship to the land to be essential to their culture and to their survival as a distinct people.",54

\section{B. Diet and Hunting}

The traditional Inuit diet relies heavily on blubber, oil, and fat from hunting seals, whales, caribou, and fish. ${ }^{55}$ While the modern diet is a bit different from what it once was, nutritious food from the south is expensive, so the foods that are able to make it into the homes of the Inuit are processed foods. ${ }^{56}$ As a result, many Inuit rely on the traditional ways of gathering food. ${ }^{57}$

Hunting is a critical part of social interaction for the Inuit. ${ }^{58}$ In the summer, small groups hunt caribou, while in the winter, many groups hunt seal. ${ }^{59}$ For centuries however, whale hunting was the central ritual of their culture and the Inuit relied on whale as their primary form of sustenance. ${ }^{60}$ Anthropologists refer to the Inuit as "People of the Whale" because the two are inextricably linked to one another. ${ }^{61}$ The ability to hunt is essential to the Inuit's psychological health. ${ }^{62}$ Prior to a hunt, some whalers "enter a period of sexual abstinence, intensive meditation, and spiritual preparation." ${ }^{, 63}$ Not surprisingly, an Inuit leader once stated:

The whale is more than food to us. It is the center of our

50. THE INUIT WAY, supra note 45.

51. ThE INUIT WAY, supra note 45.

52. THE INUIT WAY, supra note 45.

53. ThE INUIT WAY, supra note 45.

54. THE INUIT WAY, supra note 45.

55. THE INUIT WAY, supra note 45 , at 42.

56. The INUIT WAY, supra note 45 , at 42.

57. The INUIT WAY, supra note 45, at 43.

58. The INUIT WAY, supra note 45 , at 30.

59. The INUIT WAY, supra note 45.

60. Rupa Gupta, Note, Indigenous Peoples and the International Environmental Community: Accommodating Claims Through a Cooperative Legal Process, 74 N.Y.U. L. REV. 1741, 1771 (1999).

61. Id. at 1745 .

62. Id. at 1746 .

63. Id. at 1747 (quoting Nigel BonNer, Whales OF THE World 61 (1989)). 
life and culture. We are the People of the Whale. The taking and sharing of the whale is our Eucharist and Passover. The whaling festival is our Easter and Christmas, the Arctic celebrations of the mysteries of life. ${ }^{64}$

While whale hunting is essential to many Inuit groups, others depend on seals, walrus, polar bears, and land mammals such as caribou, reindeer, moose, and musk ox. ${ }^{65}$ To hunt, catch, and share these foods is the essence of Inuit culture." ${ }^{, 66}$ When the numbers of these animals decline, it "threatens not only the dietary requirements of the Inuit, but also their very way of life." ${ }^{, 67}$

\section{Inuit Role as Lawmakers}

Indigenous peoples have moved from the object to the subject of international law in the last decades. ${ }^{68}$ Indigenous peoples have gained recognition of their "legal personality as distinct societies" with special collective rights and a role in national decision-making. ${ }^{69}$ International efforts have been shifting to the creation of "practical programs for indigenous self-development." ${ }^{70}$ These efforts have secured international legal recognition for the Inuit, ${ }^{71}$ and they have established themselves as relatively autonomous groups. ${ }^{72}$

The United Nations has attempted to define "good" practices when it comes to indigenous peoples'orole in decision-making. ${ }^{73}$ The Human Rights Security Council stated: "The most significant indicator of good practice is likely to be the extent to which indigenous peoples were involved in the design of the practice and their agreement to it." ${ }^{, 74}$ The Council then listed other factors: "(a) Allows and enhances indigenous

64. Id. (quoting The People of the Whale: A Fight for Survival, 98 InDian AfFairs FallWinter 7 (1978-79)).

65. Susan Joy Hassol, Arctic Climate Impact Assessment: Impacts of a Warming ARCTIC 93 (2004).

66. Id. at 94 .

67. Id.; see also Gupta, supra note 60, at 1748 ("From the Inuit's perspective, the disruption of this use not only raises the specter of losing the whale meat in their diet and economy, but also poses the threat of cultural, social, and spiritual starvation.").

68. Russell Lawrence Barsh, Indigenous Peoples in the 1990s: From Object to Subject of International Law, 7 HARv. HuM. RTS. J. 33, 35 (1994).

69. Id. at 34.

70. Id.

71. $I d$. at 35 .

72. $I d$. at 57.

73. See Human Rights Council, Final report of the study on indigenous peoples and the right to participate in decision-making, Aug. 17. 2011, UN Doc. A/HRC/18/42 (2011) [hereinafter Indigenous Decision-Making].

74. Id. at 4. 
people's participation in decision-making, (b) Allows indigenous peoples to influence the outcome of the decisions that affect them, (c) Realizes indigenous peoples' right to self-determination, (d) Includes, as appropriate, robust consultation procedures and/or processes to seek indigenous peoples' free, prior, and informed consent.", 75

The Inuit have distinctly different experiences with self-determination and legal rights depending on their "nationality."

\section{Sami Parliaments}

In Sweden, Norway, and Finland, the Inuit peoples are referred to as the Sami. ${ }^{76}$ In each of these nations, the indigenous peoples have their own parliament. ${ }^{77}$ In Sweden, the Sami Parliament has special responsibilities in regard to decision-making. ${ }^{78}$ The Swedish Sami Parliament decides on the distribution of financing, the members of the Sami schools, and participates in decisions affecting the interests of the reindeer industry. ${ }^{79}$

In Finland and Norway, authorities are required to negotiate with the Sami Parliament in all matters that would affect the status of the indigenous people. $^{80}$ The Norwegian Sami also have the right to set out procedures applicable to the government in all issues directly affecting Sami interests. ${ }^{81}$

\section{Greenland's Home Rule}

Greenland's Parliament is entirely indigenous. ${ }^{82}$ Under the Home Rule Act of 1979, Denmark slowly transferred control to Greenlandic authorities and its population of $56,000 .{ }^{83}$ The result of the process "is often considered a model for other indigenous peoples, perceived by some as being the maximum degree of autonomy that a small indigenous group can hope to achieve." ${ }^{\prime 4}$ Greenland is now a self-governing region in nearly full control of its own daily affairs. ${ }^{85}$ Greenland does, however, rely on Denmark for nearly half of its public expenditures, "a fact that

75. Id.

76. Permanent Forum on Indigenous Issues, Indigenous participatory mechanisms in the Arctic Council, the Circumpolar Inuit Declaration on Resource Development Principles in Inuit Nunaat and the Laponia management system, May 7-18, 2012, 11, UN Doc. E/C.19/2012/10 (2012) [hereinafter Indigenous Participatory Mechanisms].

77. Indigenous Decision-Making, supra note 73, at 7.

78. Indigenous Decision-Making, supra note 73, at 7.

79. Indigenous Decision-Making, supra note 73, at 8.

80. Indigenous Decision-Making, supra note 73 , at 8 .

81. Indigenous Decision-Making, supra note 73 , at 8 .

82. Indigenous Decision-Making, supra note 73 , at 8.

83. AN INDIGENOUS PARLIAMENT, supra note 46, at 150.

84. AN INDIGENOUS PARLIAMENT, supra note 46, at 150.

85. An Indigenous Parliament, supra note 46 , at 150. 
psychologically at least perpetuates a dependency complex reminiscent of colonialism." ${ }^{\circ 6}$ While Greenland is not fully independent, Home Rule grants the indigenous population a high level of autonomy.

\section{The United States' Alaska Native Claims Settlement Act}

In the United States, on the other hand, the Alaska Native Claims Settlement Act of 1971 granted the Inuit 45 million acres of land and $\$ 962.5$ million to compensate for the remaining 88 percent of the Inuit land claims. ${ }^{87}$ The agreement lacked any recognition of self-determination. ${ }^{88}$ For-profit corporations received the compensation, and "they have not been characterized as examples of good corporate governance or corporate democracy." ${ }^{, 89}$ On the other hand, Alaska has granted local control through borough governments. ${ }^{90}$ The Inuit are able to participate extensively in governance in the North Slope Borough and Northwest Arctic Borough. ${ }^{91}$

The United States' system is in direct violation of articles 20 and 33 of the Declaration on the Rights of Indigenous Peoples, which grant indigenous peoples the right to "maintain and develop their political, economic, and social systems and institutions," and to "determine their own identity or membership in accordance with their customs and traditions." 92 The International Covenant on Economic, Social and Cultural Rights of 1966 also states that "[i]n no case may a people be deprived of its own means of subsistence," 93 and the Alaska Native Claims Settlement Act did just that. ${ }^{94}$

\section{Canadian Land Agreements}

In Canada, the approximately 56,000 Inuit benefit from land agreements that enable them to exercise a great deal of control over their futures. ${ }^{95}$ These land agreements were the James Bay and Northern Quebec

86. AN INDIGENOUS PARLIAMENT, supra note 46, at 152.

87. See Indigenous Participatory Mechanisms, supra note 76, at 6 .

88. Indigenous Participatory Mechanisms, supra note 76, at 7.

89. Indigenous Participatory Mechanisms, supra note 76, at 7.

90. Indigenous Participatory Mechanisms, supra note 76, at 7.

91. Indigenous Participatory Mechanisms, supra note 76, at 7.

92. Indigenous Participatory Mechanisms, supra note 76, at 7.

93. Indigenous Participatory Mechanisms, supra note 76, at 7.

94. Indigenous Participatory Mechanisms, supra note 76, at 8. It should be noted, however, that the United States has signed but not ratified the International Covenant on Economic, Social and Cultural Rights. Chapter IV: Human Rights, United StATES TREATY COLlection (Aug. 27, 2014, 9:12 PM), https://treaties.un.org/pages/ viewdetails.aspx?chapter $=4 \&$ lang=en\&mtdsg_no=iv-3\&src=treaty, archived at http://perma.cc/D6UD-RMTW.

95. Inuit, HistORICA CANADA (Aug. 6, 2010), http://www.thecanadianencyclopedia.ca/ en/article/inuit/, archived at http://perma.cc/MWZ6-FPLJ. 
Agreement, the Inuvialuit Final Agreement, the Nunavut Land Claims Agreement, and the Labrador Inuit Land Claims Agreement. ${ }^{96}$ The Canadian government needed to establish a common understanding of law, as Inuit's community customs had run counter to the basic principles of Canadian law. ${ }^{97}$ There was no formal authority to decide how a social infraction should be punished, as "the entire community was responsible for the maintenance of peace and order." 98 Social issues were addressed as an entire group, and the response focused more on the individual than on the offense. $^{99}$

The major differences between the Alaska Native Land Claims Agreement and the James Bay and Northern Quebec and Inuvialuit Land Claims Agreement are that the Canadian agreements included "actual and extensive negotiations," rather than an act of Congress, and a "full and formal" referendum that allowed for free, prior, and informed consent. ${ }^{100}$ Additionally, the agreements formally recognized the fishing, hunting, and gathering rights of the indigenous peoples. ${ }^{101}$ While the Nunavut Land Claims Agreement has been unsuccessful, the Labrador Inuit Land Claims Agreement of 2004 contains key provisions in favor of Inuit interests. ${ }^{102} \mathrm{It}$ addresses offshore water rights and specifies self-government. ${ }^{103}$

\section{Russian Limitations}

The United Nations points out that in Russia, "neither local nor national authorities have provided any substantive response to the appalling conditions facing the approximately 1,700 Siberian Yup'ik. ...104 The United Nations further states that "[t]he Inuit do not have any measure of control over or direct participation in" the rapid industrialization in the northern part of Russia. ${ }^{105}$ In 2001, however, the Russian Federation passed a law to grant permanent legal status to indigenous communities, but "[f]ew, if any, of these minimal laws have been implemented to date."106

Because every nation has a unique approach to the status of the Inuit population, each must work together in other forums and with NGOs in order to raise awareness of their claims to human rights, particularly as they apply to climate change.

\footnotetext{
96. See Indigenous Participatory Mechanisms, supra note 76, at 8-10.

97. The InUIT WAY, supra note 45, at 15.

98. The InUIT WAY, supra note 45 , at 15.

99. The InUIT WAY, supra note 45 , at 13.

100. Indigenous Participatory Mechanisms, supra note 76, at 8.

101. Indigenous Participatory Mechanisms, supra note 76, at 8.

102. Indigenous Participatory Mechanisms, supra note 76, at 9.

103. Indigenous Participatory Mechanisms, supra note 76, at 9.

104. Indigenous Participatory Mechanisms, supra note 76, at 6.

105. Indigenous Participatory Mechanisms, supra note 76, at 6.

106. Indigenous Participatory Mechanisms, supra note 76, at 6.
} 


\section{Climate Change IN THE ARCTIC}

\section{A. Global Warming}

Global warming is a very real phenomenon that will have profound effects on the entire world, particularly the Arctic. ${ }^{107}$ Earth's average temperature has increased by 1.4 degrees Fahrenheit over the last century, and could rise another 2 to 11.5 degrees Fahrenheit in the next. ${ }^{108}$ These small changes can lead to significant changes in the climate and weather. ${ }^{109}$ Data from tree rings show that the summer temperatures over the last decades are the highest they have been in 2,000 years, and snow cover in May and June has decreased by 20 percent. ${ }^{110}$ The Arctic is one of the parts of the globe that is warming up the fastest. ${ }^{11}$

There are five reasons why the Arctic is warming faster than lower parts of the world. ${ }^{112}$ First, melting snow exposes darker land, absorbing more light. ${ }^{113}$ Second, "a greater fraction of the extra energy received at the surface due to increasing concentrations of greenhouse gases goes directly into warming the atmosphere," 114 while in the tropics, more goes to evaporation. ${ }^{115}$ Third, the atmospheric layer is shallower in the Arctic, which means that the air is able to heat more quickly. ${ }^{116}$ Fourth, the retreating sea ice exposes more water, and "solar heat . . . is more easily transferred to the atmosphere . . ."117 Finally, oceanic circulation transfers heat to the Arctic. ${ }^{118}$

GHG emissions are a major culprit. ${ }^{119}$ GHGs like carbon dioxide, methane, and nitrous oxide trap heat into Earth's atmosphere, causing global temperatures to rise. ${ }^{120}$ In general, GHGs contribute to a necessary

\footnotetext{
107. HASSOL, supra note 65 , at 8 .

108. Climate Change: Basic Information, US Envtl. Protection Agency, http://www.epa.gov/climatechange/basics/ (last visited Jan. 16, 2014, archived at http://perma.cc/YW6T-NM7T).

109. Id.

110. Margareta Johanasson, Effects of Climate Change in Arctic More Extensive Than $\begin{array}{llll}\text { Expected, Report Finds, SCIENCEDAILY } & \text { (May } & 4, & \text { 2011), } \\ \text { http://www.sciencedaily.com/releases/2011/05/110504084032.htm, } & \text { archived }\end{array}$ http://perma.cc/6B8V-WFC4.

111. Id.

112. HASSOL, supra note 65 , at 20.

113. HASSOL, supra note 65 , at 20.

114. HASSOL, supra note 65, at 20.

115. HASSOL, supra note 65, at 20.

116. HASSOL, supra note 65 , at 20.

117. HASSOL, supra note 65 , at 20.

118. HASSOL, supra note 65 , at 20.

119. See Climate Change: Basic Information, supra note 108.

120. HASSOL, supra note 65, at 20.
} 
process that regulates the global temperatures. ${ }^{121}$ Carbon sinks like plants, trees, and oceans absorb excess GHGs to stabilize the amount in the atmosphere. ${ }^{122}$ Global carbon dioxide emissions from fossil fuels alone have increased by 1,600 percent since the turn of the twentieth century. ${ }^{123}$

In the past several decades, the Arctic Ocean has warmed two to three degrees Celsius and is expected to warm by as much as ten degrees Celsius by $2100 .{ }^{124}$ The concern is that the warming could be so rapid that adaptation would be impossible, and migration would be the only solution. ${ }^{125}$ In addition to Kivalina, ${ }^{126}$ two Alaskan villages have already been forced to relocate as a result of permafrost thaw, one of which must move to the outskirts of a Canadian town, which would threaten its subsistence, lifestyle, and identity. ${ }^{127}$

Permafrost thaw and changes in hunting patterns are two areas where the impact of climate change will be the greatest. ${ }^{128}$ Permafrost is "soil, rock, or sediment that has remained below $0^{\circ} \mathrm{C}$ for two or more consecutive years." "It exists under most land surfaces and can range from a "few meters to several hundred meters thick."130

Much of the region's industrial activities depend on the frozen ground for transportation. ${ }^{131}$ When the top layer of permafrost thaws, the roads become muddy and unstable. ${ }^{132}$ Northern villages rely on frozen roads to receive groceries and other materials. ${ }^{133}$

Permafrost thaw can also cause damage to houses, roads, airports, and pipelines. ${ }^{134}$ Current projections indicate that it is very likely that

121. Annette Saliken, Cocktail Party Guide to Global Warming 23 (Heritage House Publ'g 2010).

122. Id. at 28 .

123. Global Greenhouse Gas Emissions Data, US Envtl. Protection Agency, http://www.epa.gov/climatechange/ghgemissions/global.html (last visited Jan. 16, 2014, archived at $\mathrm{http}: / /$ perma.cc/53ZK-3LFZ).

124. GOLDBERG, supra note 3 , at 4.

125. GOLDBERG, supra note 3, at 4.

126. See discussion supra Part I.A.

127. See discussion supra Part I.A.; see also Thin Lei Win, Alaksan Villagers Become Climate Refugees as Homeland Melts, Thomson Reuters Found. (April 24, 2012, 3:11 PM), http://www.trust.org/alertnet/news/alaskan-villagers-become-climate-refugees-ashomeland-melts, archived at http://perma.cc/A4PS-CKE8.

128. Brad Plumer, Permafrost Thaw- Just How Scary Is It?, Washington Post (Dec. 19, 2011, 1:07 PM), http:/www.washingtonpost.com/blogs/ezra-klein/post/just-how-scary-ispermafrost-thaw/2011/12/19/gIQAUE4j4O_blog.html, archived at http://perma.cc/L7ER$854 \mathrm{~B}$.

129. HASSOL, supra note 65 , at 87.

130. HASSOL, supra note 65 , at 87.

131. HASSOL, supra note 65 , at 86 .

132. HASSOL, supra note 65 , at 86 .

133. HASSOL, supra note 65 , at 86 .

134. GoldBerG, supra note 2 , at 5. 
permafrost thaw will cause settling. In Yakutsk, Russia, more than 300 buildings have been damaged by permafrost thaw. ${ }^{135}$ These buildings include several residential buildings, a power station, and the airport's runway. ${ }^{136}$ While some argue that poor construction caused the buildings to collapse, there are serious limitations to the quality of construction while permafrost continues to thaw. ${ }^{137}$ Complete thawing is expected to take centuries, and the benefits of easier construction will not occur until after that time. ${ }^{138}$ Therefore, the consequences over the next century will be "primarily negative (that is, destructive and costly)." 139

Another crucial aspect of permafrost thaw is that permafrost is also an important carbon sink. ${ }^{140}$ As permafrost melts, more and more of the trapped methane and carbon dioxide are released. ${ }^{141}$ There is evidence that by the year 2100 , the carbon released from permafrost could be five times greater than current models indicate. ${ }^{142}$

Climate change also affects the Inuit's ability to hunt. In the Nunavut territory, the sea ice is thinning, and there is a reduction in the number of seals in some areas. ${ }^{143}$ In an Inuit community's spring narwhal hunt, where villagers rely on hunting about sixty narwhal every year, hunters were only able to harvest three whales. ${ }^{144}$ Furthermore, populations of marine mammals, caribou, and polar bears are declining. ${ }^{145}$ Seals and walruses are losing their "platform" to rest, and there are reports of caribou falling through sea ice. ${ }^{146}$ There is also a shorter hunting season because of the shorter freezing period.

The Arctic Climate Impact Assessment compiled indigenous observations in its report and stated that "a number of common themes clearly emerge." 147 These are: "the weather seems unstable;" "snow quality and characteristics are changing;" "there is more rain in the winter;" "seasonal weather patterns are changing;" "water levels in many lakes are dropping;" "species not seen before are now appearing in the Arctic;" "sea ice is declining, and its quality and timing are changing;" "storm surges are increasing erosion in some areas; more groups are reporting sunburn;" "climate change is occurring faster than the people can adapt;" and "climate

135. HASSOL, supra note 65 , at 89 .

136. HASSOL, supra note 65 , at 89.

137. HASSOL, supra note 65 , at 89.

138. HASSOL, supra note 65 , at 89.

139. HASSOL, supra note 65 , at 89.

140. SALIKEN, supra note 121 , at 28.

141. SALIKEN, supra note 121, at 28.

142. SALIKEN, supra note 121, at 28.

143. SALIKEN, supra note 121, at 28.

144. Struzik, supra note 4.

145. GOLDBERG, supra note 2, at 5.

146. GoldBERG, supra note 2, at 5.

147. HASSOL, supra note 65 , at 93. 
change is strongly affecting people in many communities, and in many cases, threatening their survival."148

\section{B. Prospect of Increased Trade and Development}

Despite the clear impacts on the Inuit, climate change in the Arctic will have positive effects for some. ${ }^{149}$ The opening of the "Northwest Passage," the long-awaited waterway through the arctic, will increase trade, fishing, and mining in once-inaccessible areas. ${ }^{150}$ While this may bring economic prosperity to some, there will be many adverse effects on the Inuit way of life. ${ }^{151}$

Explorers have been searching for the Northwest Passage since 1497 when Italian navigator John Cabot attempted the voyage. ${ }^{152}$ Many others made unsuccessful attempts, and it was not until 1905 that Roald Amundsen's vessel completed the journey. ${ }^{153}$ Since this journey about 110 vessels have completed the voyage. ${ }^{154}$ It has never been considered a truly viable trade option because it has been impossible to have a consistent trade route. ${ }^{155}$ In 2007, however, the prospect of a viable route was closer than it has ever been as Europe's Space Agency reported that the levels of sea ice were so low that the passage was fully navigable for the first time since satellite records began. ${ }^{156}$ In 2007, Roger Swanson, "a 76-year-old pig farmer turned yachtsman from Minnesota," was able to complete the journey in just forty-five days and described the journey as "smooth sailing." 157

Shell Oil has worked to secure oil rights in the area for the last six years, ${ }^{158}$ knowing that the thawing of the sea ice will make oil wells a viable

148. HASSOL, supra note 65 , at 93.

149. GOLDBERG, supra note 2, at 7.

150. Alistair MacDonald, Inuit Group Seeks to Attract Mining Investment in Arctic, WALL ST. J. (Sept. 26, 2012, 12:43 PM), http://online.wsj.com/article/ SB10000872396390443916104578020330254195480.html, archived at http://perma.cc/L7ER$854 \mathrm{~B}$.

151. Jonathan Montpetit, Economic Benefits of Northwest Passage Opening Not Without Costs: Researchers, REDORBIT (Aug. 13, 2007), http://www.redorbit.com/news/ science/1032743/economic_benefits_of_northwest_passage_opening_not_without_costs_res earchers/, archived at http://perma.cc/8RXN-YBR9; GOLDBERG, supra note 2, at 4.

152. Tony Soper, The Northwest Passage Atlantic to Pacific: A Portrait and GuIDE 7, (Bradt 2012).

153. Id.

154. Kathryn Westcott, Plain Sailing on the Northwest Passage, BBC News (Sept. 19, 2007, 12:18 PM), http://news.bbc.co.uk/2/hi/americas/6999078.stm, archived at http://perma.cc/DS9L-NGZQ.

155. Id.

156. $I d$.

157. Id.

158. Clifford Krauss, Shell Delays Arctic Oil Drilling Until 2013, N.Y. TIMES (Sept. 17, 
option. Shell Oil has recently been forced to halt its completion of oil wells in the Alaskan Arctic until 2013 after a "spill containment dome was damaged during a testing accident." $" 159$ Energy experts say that there could be up to a million barrels of oil a day from the region, which would be the equivalent of about 10 percent of the current United States domestic production. $^{160}$

Put simply, climate change is not an ephemeral issue. Soon every nation will be competing for oil rights and trade passages throughout the Arctic, which will only accelerate environmental degradation in the area and further deepen the human rights infringements against the Inuit from the developed world.

\section{The Environmental Justice Movement}

In recent years, protection of the environment has regained momentum. One of these areas of concern is called "Environmental Justice." The US EPA defines Environmental Justice as "the fair treatment and meaningful involvement of all people regardless of race, color, national origin, or income with respect to development, implementation, and enforcement of environmental laws, regulations, and policies." 161 The EPA further adds, environment justice "will be achieved when everyone enjoys the same degree of protection from environmental and health hazards and equal access to the decision-making process to have a healthy environment in which to live, learn, and work." "162

Since the 1980s, the US population has become more aware of the disparate effects of environmental degradation, including the realization that ${ }^{163}$ most environmental damage is done in low-income, high-minority areas. ${ }^{164}$ Minorities are disproportionately affected by environmental change. ${ }^{165}$ In fact, "people of color now comprise a majority in neighborhoods with commercial hazardous waste facilities."166

Furthermore, "from extraction to distribution to consumption, Indigenous peoples in the U.S. are disproportionately impacted all along the

2012), http://www.nytimes.com/2012/09/18/business/global/shell-delays-arctic-oil-drillinguntil-next-year.html?pagewanted=all, archived at http://perma.cc/9V8D-5PMD.

159. Id.

160. Id.

161. Environmental Justice, United States Envtl. Protection Agency, http://www.epa.gov/environmentaljustice/ (last updated Nov. 19, 2013, archived at http://perma.cc/VG8Y-TH5N.

162. Id.

163. Robert Bullard, et al., Toxic Wastes and Race at Twenty: 1987-2007, 38

(United Church of Christ 2007), archived at http://perma.cc/S7NG-G86J.

164. Id. at 52 .

165. Id. at 63 .

166. Id. 
road of destruction." "167 The United Church of Christ made the following statement of solidarity:

We, the undersigned, have met in a gathering on climate change and environmental justice. We have heard from scientists and policy analysts, from Arctic communities and residents of ecosystems already impacted by the effects of climate change .... The urgency of responding to climate change is undeniable; to ignore the issue means environmental and social disaster for all. The sins we commit against Mother Earth today will haunt our children and children's children tomorrow. ${ }^{168}$

That said, it is important to note that human rights violations through global warming do not present the only violations that other indigenous populations face. Indigenous populations throughout the world must contend with large-scale operations that utterly destroy their homelands. ${ }^{169}$ The impacts of these techniques are outside the scope of this Note and present issues that are no less complicated.

\section{THE ROLE OF NGOS}

\section{A. NGOs and the United Nations}

As Native Village of Kivalina indicates, there are few options for the Inuit to voice their concerns. In an attempt to encourage real change, NGOs have taken up the cause to defend the Inuit in forums ${ }^{170}$ and to bring these concerns to the United Nations. ${ }^{171}$ NGOs play a critical part in the formation of policies and treaties regarding the intersection of climate change and human rights; however, NGOs in the field largely overlook a critical element of the process - the Inuit themselves. ${ }^{172}$

Without the Inuit's active participation in these organizations, NGOs will continue to fall short of their goals of creating change for the Inuit peoples. To bring more effective claims to international bodies, NGOs must make a more concerted effort to include the Inuit voices, their people, and

\footnotetext{
167. Id. at 121 .

168. Id. at 122 .

169. See, e.g., Shell's Environmental Devastation in Nigeria, Center for CONSTitutional Rights (2009), archived at http://perma.cc/X3QY-8ZXM.

170. For a list of non-governmental organizations with consultative status, see infra note 181.

171. Gupta, supra note 60, at 1771.

172. As an observation based on the author's research: outside of the organizations created by the Inuit, Inuit leaders are rare within the NGOs that focus on the relationship of human rights and climate change.
} 
their leaders into their strategies to effect more lasting changes to the policies and decisions of international bodies. The ultimate goal is to encourage a grassroots movement to bring the Inuit concerns to the United Nations. The most effective way to do this would be to increase collaboration with Inuit populations.

NGOs are "private, independent, non-profit, goal-oriented and not founded or controlled by a government." 173 NGOs make up a part of "civil society" and have many virtues. A strong civil society is able to oppose an oppressive government and speak with the voice of the people. ${ }^{174}$ Civil society is able to organize the public for democratic participation, no matter what form of government the civil society is. ${ }^{175}$ Civil society builds trust and increases social capital. ${ }^{176}$ These are essential aspects of any grassroots movement, which is best suited to effectuate change in the United Nations.

Human rights NGOs have had a profound effect on UN policy since the United Nations'ucreation. Gay McDougall states "NGOs frame policies and influence key government decisions. They give voice to causes that have been ignored, forgotten or marginalized. They raise legal awareness within targeted communities, often providing basic legal representation in high-risk or neglected human rights cases." ${ }^{177}$ NGOs made significant contributions to the negotiation of the UN Charter and nearly all major human rights policies enacted under the Universal Declaration of Human Rights. ${ }^{178}$

NGOs have access to the United Nations through article 71 of the UN Charter. ${ }^{179}$ Article 71 provides the legal basis for NGOs to receive United Nations "consultative status." It states: "The Economic and Social Council may make suitable arrangements for consultation with non-governmental organizations which are concerned with matters within its competence. Such arrangements may be made with international organizations and,

173. George E. Edwards, Assessing the Effectiveness of Human Rights NonGovernmental Organizations (NGOs) From the Birth of the United Nations to the 21st Century: Ten Attributes of Highly Successful Human Rights NGOs, 19 MicH. ST. J. InT'L. L. 165,170 (2010). The definition of an NGO is not without dispute; however, these are the assumed minimal characteristics of an NGO.

174. Nancy L. Rosenblum \& Robert C. Post, Introduction to Civil Society and Government 17 (Nancy L. Rosenblum and Robert Post eds., 2002).

175. Id. at 18 .

176. Id.

177. Edwards, supra note 173, at 175 (quoting Gay McDougall, Decade of NGO Struggle, 11 Hum. RTS. BRIEF 12 (2004)).

178. Edwards, supra note 173, at 176; see also William Korey, NGOs and the Universal Declaration of Human Rights: “A Curious Grapevine”, 22 HuM. RTS. Q. 298 (2000) (book review) (declaring that human rights NGOs have been "instrumental" in making human rights discourse significant).

179. U.N. Charter art. 71. 
where appropriate, with national organizations . . .."180 Currently, there are seven NGOs with a stake in Inuit affairs that have consultative status with the United Nations. ${ }^{181}$ Article 71 has been considered a great success, as former Secretary-General of the United Nations, Kofi Annan stated: "Close engagement with civil society was seen then as vital for the Organization's health and for people's well-being. That is as true today as it was then-if anything, even more so." 182

\section{B. Effective Strategies for Human Rights NGOs}

Professor George Edwards of Indiana University Robert $\mathrm{H}$. McKinney School of Law outlines ten characteristics of effective Human Rights NGOs. These are: (1) mission, (2) adherence to human rights principles, (3) legality, (4) independence, (5) funding, (6) non-profit status and commitment to service, (7) transparency and accountability, (8) adaptability and responsiveness, (9) cooperative and collaborative nature, and (10) competence and reliability. ${ }^{183}$

The same characteristics should hold true for successful NGOs that pursue environmental justice claims. These characteristics are important when considering a change in the organizational make-up of major NGOs with a stake in Inuit affairs and well-being.

Three major NGOs, Earthjustice, the Center for International Environmental Law, and Earthrights International, have established three different techniques for advancing environmental human rights claims. ${ }^{184}$ The first of these, championed by Earthjustice, is to work through the UN system toward establishing environmental rights as enforceable law. ${ }^{185}$ The

180. Id.

181. See United Nations Economic and Social Council, List of NonGOVERnMENTAL ORganizations in CONSUltative STATUS With THE ECONOMIC AND Social COUNCIL AS OF 1 SEPTEMBER 2011 (2011), archived at http://perma.cc/P7Y-Y66S. The seven organizations are the Inuit Circumpolar Council; Pauktuutit Inuit Women's Association of Canada; Earthjustice; the Association of Indigenous Peoples of the North, Siberia and Far East of the Russian Federation; the Batani International Development Fund for Indigenous People of the North, Siberia and the Far East of the Russian Federation; the International Work Group for Indigenous Affairs; and the Netherlands Centre for Indigenous Peoples. Each of these, according to their mission statements, has an interest in Inuit affairs. See, e.g., Mission Statement, INT'L WORK GROUP FOR INDIGENOUS AFFAIRS, http://www.iwgia.org/iwgia/who-we-are-/mission-statement (last visited Jan. 20, 2014, archived at http://perma.cc/EQ89-RZS6).

182. Edwards, supra note 173, at 177 (quoting Press Release, U.N. Secretary-General, Without vital role of NGOs, world could hardly respond to myriad crises U.N. SecretaryGeneral Annan tells DPI/NGO Conference, U.N. Press Release SG/SM/10085 (Sept. 9, 2005)).

183. Edwards, supra note 173, at 168.

184. Cassel, supra note 2, at 107.

185. Cassel, supra note 2, at 107. 
second strategy is to enforce human rights claims on a regional level, particularly through the submission of petitions to the Inter-American Commission of Human Rights (IACHR), as the Center for International Environmental Law (CIEL) has been doing. ${ }^{186}$ Third, Earthrights International submits amicus briefs in litigation in US Federal Courts under the Alien Torts Claims Act. ${ }^{187}$

The submission of Environmental Rights Reports to the UN Human Rights Commission has its limitations. ${ }^{188}$ Because the Commission is unable to produce "concrete, immediate benefits" for the parties involved, it may not be the most desirable approach. ${ }^{189}$ CIEL's approach of petitioning the IACHR also has its limitations, most notably in regard to enforcement. ${ }^{190}$ Moreover, '[m]any of the governments with which the Inter-American Commission . . . [has] had to work have been ambivalent towards [it] at best and hostile at worst.",191

Given the deficiencies of a court-based approach, all three of these organizations would benefit immensely by increasing their efforts to collaborate with Inuit leaders and assist in creating a more grassroots approach.

\section{CURRENT StATUS OF NGOS}

\section{A. Human Rights and Climate Change}

Currently, the United Nations has recognized the impact of climate change on human rights; however, little more has been done to combat the problem. In Resolution 10/4, the Human Rights Council decided to hold a panel discussion on the relationship between climate change and human rights. ${ }^{192}$ In the discussions, the United States denied that there was a link between climate change and human rights as a legal matter but did recognize that climate change could impede the full enjoyment of rights. ${ }^{193}$ Other nations recognized the critical problems with climate change and human rights and stated that the issues impacted their own people as well. ${ }^{194}$

186. Cassel, supra note 2, at 107 .

187. Cassel, supra note 2, at 107 .

188. Cassel, supra note 2, at 110.

189. Cassel, supra note 2, at 110 .

190. Cassel, supra note 2, at 118.

191. Cassel, supra note 2, at 118. (quoting Henry J. Steiner \& Philip Alston, International Human Rights in Context: Law, Politics, Morals 938 (2d ed. 2000)).

192. See generally OfFice of the High COMm'R FOR Human Rights, Summary of Discussions, Human Rights Council Panel Discussion on the Relationship Between Climate Change And Human Rights (2009), archived at http://perma.cc/A86X-NXK3.

193. Id. at 8 .

194. Id. at 7. China, Azerbajian, the EU, Turkey, and others stated that their respective populations were already affected by climate change. Id 
It is important to point out that the discussions were silent on the impact of climate change on the Inuit populations. ${ }^{195}$ The most concrete resolution, however, was to "explore in more detail how a human rights approach could strengthen policies and measures and enhance the protection of human rights in the face of the climate."196

In October 2011, the Human Rights Council made greater strides in the relationship of human rights and climate change, as it recognized the intersection as a true problem. ${ }^{197}$ Resolution 18/22 emphasizes that:

Climate-change related impacts have a range of implications, both direct and indirect, for the effective enjoyment of human rights, including, inter alia, the right to life, the right to adequate food, the right to the highest attainable standard of health, the right to adequate housing, the right to self-determination and the right to safe drinking water and sanitation, and recalling that in no case may a people be deprived of its own means of subsistence. ${ }^{198}$

The resolution further recognizes that climate change is "a global problem requiring a global solution, and that effective international cooperation . . . is important in order to support national efforts." 199 The resolution asks for a seminar addressing the adverse impacts of climate change on human rights to forge a "stronger interface and cooperation between human rights and climate change communities" ${ }^{200}$ and asks for the invitation of civil society organizations and representatives from "those segments of the population most vulnerable to climate change."201

Indigenous peoples, however, are often weary of a top-down approach. An author for an indigenous peoples'nnews outlet, mediaINDIGENA, asked the question: "Do non-Aboriginal people have the right to lead aboriginal struggles?" 202 The article came after a lawyer acted "on behalf" of Inuit in their land claims. ${ }^{203}$ The author's assumption, and

195. See id. Canada did note that while changes should be enacted by the States, if anyone within its borders had a claim, its domestic laws would apply. Id.

196. Id. at 17.

197. See generally Human Rights Council Res. 18/22, Rep. of the Human Rights Council, 18th Sess., Sept. 30, 2011, U.N. Doc A/HR/RES/18/22 (Oct. 17, 2011).

198. Id. at 2 .

199. Id. at 2-3.

200. Id. at 3 .

201. Id.

202. Rick Harp, Do Non-Aboriginal People Have the Right to Lead Aboriginal Struggles?, MEDIAINIDIGENA (Jan. 15, 2011, 3:11 PM), http://www.mediaindigena.com/rickharp/issues-and-politics/do-non-aboriginal-people-havetheir-right-to-lead-aboriginal-struggles archived at http://perma.cc/J76B-LW2J.

203. Id. 
the assumption from others, is that the attorney was simply looking to collect money from a settlement.

While the skepticism that the attorney was predatory may be meritless, there is a strong point to be made about the distrust of nonindigenous by indigenous peoples. If an attorney attempting to represent indigenous peoples in their land claims is considered predatory, how can an organization that lacks active internal participation of the people it seeks to serve be given any credibility?

Generally, people have a different attitude towards civil society than they do to lawyers as a group. The essential question, however, is how civil society can bring more effective claims to the United Nations. By seeking out more Inuit leaders for management positions and increasing efforts for collaboration, the active NGOs will be able to build a stronger culture of leadership.

\section{B. The Effectiveness of Inuit Voices}

The Inuit Circumpolar Council (ICC) and Arctic Council are organizations designed to voice concerns for Inuit people. The ICC was founded in 1977 as an NGO to represent the 150,000 Inuit of Alaska, Canada, Greenland, and Russia and now has special consultative status with the United Nations. ${ }^{204}$ On its website, the ICC states that "to thrive in their circumpolar homeland, Inuit had the vision to realize they must speak with a united voice on issues of common concern and combine their energies and talents toward protecting their way of life."205 The organization has four principal goals: (1) "to strengthen unity among Inuit of the circumpolar region;" (2) "to promote Inuit rights and interests on an international level;" (3) "to develop and encourage long-term policies that safeguard the Arctic environment;" and (4) "to seek full and active partnership in the political, economic, and social development of circumpolar regions."206

The ICC and the Inuit have "long been champions of the environment." ${ }^{207}$ According to the ICC Principles in 1992:

It is a fundamental objective of the Arctic policy to protect the delicate environment, including the marine and other resources on which the Inuit depend. The right to a safe and healthy environment is an emerging human right and is

204. Inuit Circumpolar Council (ICC), InUit Circumpolar Council (CANADA), http://inuitcircumpolar.com/index.php?ID=16\&Lang=En (last visited Jan. 18, 2014, archived at http://perma.cc/3HB8-R2LN).

205. Id.

206. Id.

207. Barry Zellen, On Thin Ice: The Inuit, the State, and the Challenge of ARCTIC Sovereignty 36 (Lexington Books 2009). 
especially important to the Inuit . . . . Within the vast Inuit homeland, Inuit have the right and responsibility to ensure the integrity of the circumpolar environment and its resource, as a continuing source of life, livelihood and well-being for present and future generations. ${ }^{208}$

The United Nations recognizes the ICC as a "good example of regional cooperation between indigenous peoples." 209 The United Nations cites the ICC's quadrennial general assemblies and associate Inuit leaders' summit as examples of the organization bringing together the leaders of the Inuit nations. ${ }^{210}$ The United Nations also underlines the important cooperative relationship that the Greenland branch of the ICC has with the government of Greenland. ${ }^{211}$

Established in 1996, the Arctic Council is an intergovernmental forum to "provide a means for promoting cooperation, coordination, and interaction among the Arctic States with the involvement of the Arctic Indigenous communities." 212 The Arctic Council has a particular focus on sustainable development and environmental protection in the Arctic. ${ }^{213}$

The Arctic Council is very active in releasing publications regarding the impact of climate change in the region and has called for a reduction in global emissions. ${ }^{214}$ It states that "the fight against climate change is an imperative common challenge for the international community and requires immediate global measures. $" 215$

In September 2012, the International Union for the Conservation of Nature (IUCN), the world's largest environmental network, "overwhelmingly approved" voting status for the Indigenous People's Union in a motion co-sponsored by the Inuit Tapiriit Kanatami (ITK). ${ }^{216}$ The ITK and Indigenous People's Union represent Inuit people's

208. Id.

209. Indigenous Decision-Making, supra note 73, at 9.

210. Indigenous Decision-Making, supra note 73, at 9.

211. Indigenous Decision-Making, supra note 73, at 12.

212. About Us, ARCTIC-COUNCIL, http://www.arctic-council.org/index.php/en/aboutus/arctic-council/history (last visited Nov. 18, 2012, archived at http://perma.cc/7AKEVVZK).

213. Id.

214. Arctic States Call for Measures to Reduce Emissions, ARCTIC CounCIL (Dec. 11, 2012), http://www.arctic-council.org/index.php/en/resources/news-and-press/newsarchive/274-arctic-council-statement-for-durban, archived at http://perma.cc/9YLV-VW3Z.

215. Id.

216. International: IUCN To Establish Committee to Consider Ways to Bring Indigenous Groups to the Table, Indigenous Peoples Issues And Resources (Sept. 17, 2012, 10:45 PM),

http://indigenouspeoplesissues.com/index.php?option=com_content\&view=article\&id=1623 8:international-iucn-to-establish-committee-to-consider-ways-to-bring-indigenous-groupsto-the-table\&catid=34\&Itemid=73, archived at http://perma.cc/CEV8-SHZS. 
concerns, ${ }^{217}$ which makes the motion a critical step in fostering a grassroots movement. The leader of the ITK stated that "for Inuit, it could mean a significant shift in the way conservation organizations view our relationship with the Arctic species, which will help in the wider recognition of our knowledge about wildlife and the environment."218

Another important organization is the Russian Association of Peoples of the North (RAIPON), which, given Russia's reluctance to grant any level of autonomy to the indigenous people, grants the Russian Inuit an important voice. RAIPON represents forty indigenous groups with a total population of 200,000 people. ${ }^{219}$ RAIPON has been steadily increasing its influence on the Russian government. ${ }^{220}$ For some time, RAIPON considered the possibility of urging the Russian government to allow an indigenous parliament like the parliaments of Finland, Norway, and Sweden. ${ }^{221}$ Though the organization recognized the hurdles to such a move, RAIPON remained optimistic about the possibility of securing its status as the official body to voice Inuit concerns. ${ }^{222}$

In November 2012, however, this all ended when the Russian Ministry of Justice ordered RAIPON to close down. ${ }^{223}$ Earth Peoples, a blog that provides updates on environmental and human rights, stated that "[d] espite Russia's horrendous environmental record in the Far North, the country is rushing to open new hydrocarbon and mineral resources in the region without necessary environmental impact assessments or public consultations." 224 Because RAIPON has opposed the government's actions to exploit natural resources in the Far North and because the organization represented the growing civil society, the Russian government shut the organization down, but reopened it in March of 2013. ${ }^{225}$ During the shutdown, Anja Salo, an adviser on indigenous people's issues, stated that "the indigenous peoples in Russia will lack a common political voice in

217. About ITK, INUIT TAPIRIIT KANATAMI, https://www.itk.ca/about-itk (last visited Nov. 17, 2012, archived at http://perma.cc/E7UZ-TYCP).

218. International: IUCN To Establish Committee to Consider Ways to Bring Indigenous Groups to the Table, supra note 216.

219. An INDIGENOUS PARLIAMENT, supra note 46, at 24.

220. AN INDIGENOUS PARLIAMENT, supra note 46, at 24.

221. An IndigenOUS PARLIAMENT, supra note 46, at 67.

222. An IndigenOUs PARLiAMENT, supra note 46, at 67.

223. Atle Staaleson, Russia's Ministry of Justice Orders Close-Down of RAIPON in What is Another Crackdown on NGOs in Russia, BARENTSOBSERVER (Nov. 12, 2012), http://www.barentsobserver.com/en/arctic/moscow-orders-closure-indigenous-peoplesorganization-12-11, archived at http://perma.cc/CN8N-J8L7.

224. RAIPON (or the Russian Association of Indigenous Peoples of the North) Ordered by Russia to Cease its Activity, EARTH PEOPLES, http://earthpeoples.org/blog/?p=2800 (last visited Jan. 18, 2014, archived at http://perma.cc/ANV9-49TR).

225. Staged RAIPON Election Taints 7th Congress, INT'L WorK GROUP FOR INDIGENOUS AFFAIRS (April 16, 2013), http://www.iwgia.org/news/search-news?news_id=776, archived at http://perma.cc/5MW8-7FNL. 
order to influence the decision-making process on the federal level.",226

The recent situation means the rest of the world must increase its efforts in this arena. The largest arctic nation temporarily shut down its most crucial body in voicing indigenous concerns at a time when it is needed most. While the framework is present, and there are other forums for Inuit people to voice their concerns, American organizations must open their doors to indigenous people to achieve greater change to force States to take real measures to reduce the impacts of climate change.

\section{GRASSROOTS AND COLLABORATION}

\section{A. Grassroots Movements}

Grassroots organizations "offer the poor the prospect of self-help and representation in the political system and development process." ${ }^{227}$ When assisting grassroots efforts, NGOs are commonly referred to as Assisting Institutions (AIs). ${ }^{228} \mathrm{NGOs}$ and AIs consistently provide these movements and groups with the "knowledge, resources, and personnel they lack; support them politically; and help them join forces to effect changes in regional or national-level policies." 229 They are also able to provide alliances and act as the liaison to other organizations. ${ }^{230}$

There is a debate over the role of AIs and NGOs in shaping a grassroots movement, as many of these organizations create a culture of dependency. ${ }^{231}$ As Mina Silberberg of Rutgers University-Camden states, "self-management by the poor and the enhancement of democracy are central aims for many community organizations; dependence, or lack of autonomy, undercuts this aim by definition." ${ }^{232}$ NGOs and AIs must "provide community groups with the resources and training they need while preserving their capacity for self-management."233 In order to do so, Silberberg argues that the NGOs must create linkages that provide help while limiting their attempts to influence the grassroots affairs. ${ }^{234}$

In application to the Inuit, key to striking this balance is that NGOs in

226. Staaleson, supra note 223.

227. Mina Silberberg, Evolution of Assistance to Grassroots Organizations: The Impact of Linkage, 20 Public Productivity \& Mgmt. Rev. 432, 432 (1997), archived at http://perma.cc/3RZ7-MWGK.

228. Id.

229. Id.

230. Mina Silberberg, Balancing Autonomy and Dependence for Community and Nongovernmental Organizations, 72 Social SERV. ReV. 47, 47 (1998), archived at http://perma.cc/KZP3-YKLS.

231. Id.

232. Id. at 48 .

233. Id.

234. Id. 
the field of Inuit rights and climate change must effectively collaborate with one another. Most importantly, however, the NGOs must be willing to collaborate with the Inuit in order to foster a grassroots effort. Given the lack of transportation and struggles of communication, NGOs in this field can provide the essential alliances necessary to build an effort that spans around the Arctic Circle.

\section{B. The Importance of Collaboration}

In 1977, the International Whaling Commission (IWC) released a statement that the populations of bowhead whales have been depleted to a population of 1,300 and ordered the Inuit to cease their whale hunting. ${ }^{235}$ The IWC further predicted that bowhead whales would go extinct even if hunting stopped. ${ }^{236}$ In response, the Inuit insisted that the bowhead whale populations had been rebounding, but the scientists dismissed these claims as "anecdotal and self-interested." 237

The Inuit claimed that the counting technique of simply picking a spot along the migration route, counting the number of visible whales, and making a statistical adjustment failed to account for the actual numbers for two reasons. ${ }^{238}$ First, the migratory paths were much wider than the scientists assumed, and second, the whales often swam beneath the ice, as the natives "could hear them day and night spouting through holes in the ice." 239

In 1984, with the help of two scientists, the Inuit were able to devise a system to collect accurate data on the numbers of bowhead whale. By placing hydrophones in the water, these researchers were able to pinpoint the locations of individual whales. ${ }^{240}$ After two years of research, this technique revealed that the actual number of bowhead whales was over $10,000{ }^{241}$ The IWC rose the Inuit's hunting quota and, in 2002, reached a level with which the natives were willing to agree. ${ }^{242}$

Inuit techniques proved to be more accurate than the peer-reviewed scientific numbers. The scientists "had to accept that there was another valid way of knowing complex facts about the environment. Indeed, for this system of many parts in constant change, the [Inuit] were able to draw broad, useful conclusions in real time, something hypothesis-based science

235. Charles Wohlforth, The Whale and the Supercomputer: On the Northern Front of Climate Change 17 (North Point Press 2004).

236. Id.

237. Id.

238. Id. at 18 .

239. Id.

240. Id. at 20 .

241. Id. at 21 .

242. Id. at 22 . 
couldn't come close to doing." ${ }^{243}$

This does not discount the importance of scientific research and Western approaches to these studies, but it underlines the importance and the need to collaborate with the indigenous populations. They have lived there for thousands of years and understand the nuances of their surrounding environment.

\section{Elements of Collaboration}

An essential element of effective NGOs is the strength of their internal culture. Russell Linden, a management educator at the University of Virginia, writes that there are seven critical elements for a successful NGO seeking to increase collaboration. ${ }^{244}$ His approach relates to American agencies and organizations, but his theories can be extrapolated into an international context. The approach is also to those in board of director positions, but collaboration can also apply on a general participant level. These following factors for collaboration can fit easily into the argument that NGOs seeking to represent the Inuit human rights claims must focus first on collaborating with the Inuit peoples.

The factors for successful collaborative NGOs are: (1) "partners have a shared, specific interest or purpose that they are committed to and can't achieve (as well) on their own;" (2) "the partners want to pursue a collaborative solution now and are willing to contribute something to the effort;" (3) "the appropriate people are at the table;" (4) "the partners have an open, credible process;" (5) "the effort has a passionate champion (or champions), with credibility and clout;" (6) "the partners have trusting relationships;" and (7) "the partners use the skills of collaborative leadership." 245

All members of the process share the same desire to protect Inuit homes and their livelihood, but none more so than the Inuit themselves. While it may be obvious, this first part of the framework is a threshold issue: any goal is irrelevant if the members involved do not share a commitment to it. ${ }^{246}$

The second factor emphasizes the importance of timing, and as it applies to the Inuit, there is no better time than now to make serious pushes toward focusing the debate on climate change. As Linden points out, "it's one thing to say that you and others have a common interest in a goal, and quite another for all of you to show your desire to contribute time and

243. Id.

244. Russell M. Linden, Leading Across Boundaries: Creating Collaborative AgenCies in A Networked World 37 (Jossey-Bass 2010).

245. Id. at 38 .

246. Id. 
resources right now." 247 While Linden outlines examples on how to create immediacy, ${ }^{248}$ there is little doubt that the indigenous people of the Arctic know that climate change is profoundly changing their lives.

The third factor is critical. Having the appropriate people "at the table" streamlines priorities and projects. Linden states that when bringing people to the organization, it is important to invite people who "[r]epresent an organization that has an interest in the issue, and can speak for that organization, have expertise and knowledge related to that issue, have a strong interest in the use, can make time to work on the team, and can bring resources to bear, if needed." 249

This latter element of the third factor presents the crucial challenge to increasing Inuit participation. They simply do not have the "resources to bear," and they are needed. This, however, is unpersuasive. While it is undeniably important to bring resources to the table, it is not the only way to effect change. A voice with the backing of an entire indigenous population will be louder than any money can buy.

The fourth factor emphasizes the NGO's transparency. ${ }^{250}$ Given the mediaINDIGENA example of an author intensely skeptical of an attorney acting on behalf of indigenous populations, ${ }^{251}$ there can be no more open and transparent process than one that includes the individuals for which the NGO is advocating. Transparency "builds trust and confidence, which are essential for collaboration to flourish." 252

The fifth factor also weighs in favor of collaboration with Inuit leaders. A champion is "someone with credibility and clout who is totally committed to the project." ${ }^{253}$ The fact that the champion must be directly involved with the outcome of the NGOs' efforts is crucial. The Inuit leader can be the face of the organization, giving it a great deal of clout. In combination with other experts and concerned individuals, an Inuit champion can be a perfect complement to an organization.

The sixth and seventh factors must be built over time, as the obvious barriers of travel and language must be overcome if NGOs take on a fully collaborative effort. Relationships are "critical to partnerships" because they help the participants stay together whenever there are setbacks. ${ }^{254}$ Knowing that the partners are fully transparent and committed to the mission, however, will quicken this process.

The largest barrier to collaboration is the cost and time of travel.

247. Id. at 40.
248. Id.
249. Id.
250. Id. at 47.
251. Harp, supra note 202 .
252. LINDEN, supra note 244 , at 47.
253. LINDEN, supra note 244 , at 49.
254. LINDEN, supra note 244 , at 56. 
From Chicago, Illinois, to Barrow, Alaska, the round-trip cost of a flight is more than $\$ 1,000$ and would take nearly twenty-four hours. ${ }^{255}$ To get to Arctic villages, the rest of the trip could take multiple days by car or snowmobile. The Inuit inhabit the entire Arctic Circle, and this only represents a small portion of what the travel costs and time would be.

\section{Horizontal Collaboration}

Collaboration, however, is not just limited vertically, but horizontally as well. As the High Commissioner Report stated, the lack of coherence between human rights and climate change organizations poses a significant obstacle appropriately assessing the link between global warming and human rights infringements. ${ }^{256}$ While it is undeniably important that the two groups of organizations communicate with one another, the organizations that already understand the relationship must first collaborate with the indigenous peoples they seek to represent.

\section{E. Inuit Leaders in Board Positions}

According to a variety of resources the first criterion for selecting a board member is to ensure that he or she has "direct knowledge about the organization's mission." ${ }^{257}$ Where an organization's mission is to improve the plight of Inuit as they are affected by human rights problems through climate change, it would be consistent to have representatives from every population they are seeking to serve. While the Center for International Environmental Law does represent indigenous voices, there is a crucial lack of any Inuit on their board. ${ }^{258}$

Although the selection of boards of directors is an "inherently risky endeavor[],"259 and there are significant limitations to including Inuit leaders on an organization's board of directions, one of the most important

255. These figures are according to a search through www.kayak.com on March 10, 2013, for flights from Chicago O'Hare to Wiley Post-Will Rogers Memorial Airport.

256. High Commissioner Report, supra note 37, at 12.

257. Kendra James, How to Choose a Board of Directors for a Nonprofit Organization, Houston ChrONICLE, http://smallbusiness.chron.com/choose-board-directors-nonprofitorganization-911.html (last visited Jan. 18, 2014, archived at http://perma.cc/ZBX9-Z7V2); see also Samantha Herman, How to Choose Your Board Members for a Nonprofit, EHow, http://www.ehow.com/how_6297584_choose-board-members-nonprofit.html (last visited Jan. 18, 2014, archived at http://perma.cc/72L9-P9JA); Greg McRay, Nonprofit Board Members - Choose Wisely, FOUNDATION GROUP (Sept. 24, 2009), http://www.501c3.org/ blog/nonprofit-board-members-choose-wisely/, archived at http://perma.cc/G8JR-69HX.

258. Board of Trustees, CENTER FOR INT'L ENVTL. LAw, http://www.ciel.org/ About_Us/Board_Trustees.html (last visited Nov. 13, 2013, archived at http://perma.cc/A5NP-CDML).

259. Rosemary O'Leary \& Lisa Blomgren Bingham, The Collaborative Public MANAger: New IdEAS FOR THE Twenty-First CEnTURy 54 (Georgetown Univ. Press 2009). 
considerations is to seek board members who enhance legitimacy. The previous elements of collaboration apply to the selection of boards of directors and the strategic selection of leaders, and NGOs seeking the highest degree of collaboration with Inuit people should consider the invitation of Inuit leaders to their boards of directors. Although there are significant barriers in regard to the cost and time of travel, international NGOs can improve their legitimacy by including Inuit leaders in major positions of their organizations.

\section{CONCLUSION}

Bringing the factors of collaboration, the United Nations'rtask to establish a coherent organizational network, and the existing practices of Inuit-based NGOs, the NGOs in the field must reach out to the Inuit populations if they are going to affect real change in the arena of climate change and human rights. The Inuit populations of the Arctic have existed for thousands of years, but as Kivalina exposes, villages are being threatened due to climate change. In order to slow down climate change, a court-based approach is insufficient. NGOs must build a grassroots effort so the United Nations has no choice but to act.

Clearly, there are barriers to acting, as major industries will see the economic gain of global warming in the Arctic; however, the Inuit peoples must have the right to preserve their homelands and determine their own fate. Only international action resulting in regulations can combat this problem.

While there are obstacles to the full implementation of collaborative efforts, the fundamental mission of these organizations is to promote the well-being of peoples everywhere. The Inuit is one of the most deeply affected cultures by climate change. Strides have been made, but not nearly enough. Indigenous people of the Arctic can become the voice of the environment most deeply impacted by global climate change.

Ultimately the forum that must make the appropriate changes is the United Nations. The United Nations will not act, however, without an outpouring of support. Remediating the human rights claims of the Inuit in the face of climate change runs directly counter to the prospect of mining and trade through the Northwest Passage. Without curbing the effects soon, there will be no way to stop it later. Adding indigenous people to the wellfunded NGOs will quicken this process by adding credibility to those who will present the claims to the United Nations. Increased indigenous participation will impress on these leaders the Inuit need for international recognition and action in order to maintain their livelihood.

Economic forces, geopolitical demands, and the prospect of mining and drilling in the Arctic are salient enough that humans can lose sight of the homes, people, and cultures they will utterly change. As Ed Stuzik states: 
In the not-too-distant future, the forces of climate change are going to transform this icy world into a new economic frontier. The end of the Arctic, as we once knew it, will be the beginning of a new chapter in history. That new chapter in history must be co-authored by the people who live there." 260

260. ZELLEN, supra note 207, at 184. 